\title{
臼歯部用コンポジットレジンの表面硬さ に及ぼす温度と有機酸の影響
}

\author{
陳克恭 -小川孝雄 - 有吉啓一一寺下正道 \\ 九州歯科大学保存学第 1 講座 (主任 : 寺下正道教授)
}

平成 2 年 4 月 26 日受理

\author{
Effects of Temperature and Organic Acids \\ on Surface Hardness of Composite Resins \\ Ker-Kong Chen, Takao Ogawa, \\ Keiichi Ariyoshi and Masamichi Terashita
}

Department of Operative Dentistry (Chief: Prof. Masamichi Terashita)

Kyushu Dental College, Kitakyushu, Japan

Composite resin restorations have to tolerate the occlusal force and environmental changes during drinking and food-taking. In this study, the degradation of the composite resin was examined in terms of the changes in Knoop hardness when the specimen was stored in air or water at various temperatures $\left(25-70^{\circ} \mathrm{C}\right)$. The effects of ethanol and three kinds of organic acids were also determined.

It was found that the surface hardness of the specimen decreased with increase in temperature either in air or in water condition. The decrease was smaller in air than in water. The resins containing crystallized filler seemed to show larger reduction in hardness than those containing non-crystallized filler.

The resins stored either in ethanol or in any of the organic acids appeared to have a marked decrease in hardness as compared to those stored in air. The decrease was the most prominent in ethanol or acetic acid, next in propionic acid and the least in lactic acid.

Key words : Composite resin/Knoop hardness/Temperature/Ethanol/Organic acid

\section{緒言 \\ コンポジットレジンは田歯部用修復材料としても臨床} で使用されつつある。修復に使用された臼歯部用レジン は, 咀嚼, 温度, 唾液, 摂取した飲食物, プラークおよ びそれらに起因する有機酸1,22などの刺激を受ける状態に あり，これらの刺激によって，レジンの劣化が早められ ることは十分予想できる。従って，これらの刺激は臼㐘 部用レジンの寿命にかかわる重要な区子だと考えられて
いる39)。特にコンポジットレジンの表層はこれらの因子 に最も早く触れるため, 影響も早く現れるものと考えら れる。

そこで今回, 市販臼歯部用レジン 9 種類と前㐘部用レ ジン 1 種類を用いて, 温度変化ならびにエタノールおよ び有機酸浸漬による影響を表面硬さの変化で追ってみ たo

\section{実験材料}


Table 1 Materials used

\begin{tabular}{|c|c|c|c|c|}
\hline \multirow{2}{*}{ Material } & \multirow{2}{*}{ Abbr. } & \multirow{2}{*}{ Polymerization } & \multicolumn{2}{|l|}{ Filler } \\
\hline & & & Type & Wt (\%) \\
\hline Clearfil FII & CLF & Chemical & Quartz & 76.3 \\
\hline Clearfil Posterior & CLP & Chemical & Quartz & 80.1 \\
\hline $\mathrm{P}-10$ & P10 & Chemical & Quartz & 83.1 \\
\hline Bell Feel & BEL & Chemical & $\mathrm{Si}_{3} \mathrm{~N}_{4}+$ Quartz & 80.0 \\
\hline Profile & $\mathrm{PRO}$ & Chemical & Strontium glass & 78.7 \\
\hline Microrest AP & MAP & Chemical & Silica & 45.7 \\
\hline Palfique & PAL & Chemical & Silica & 65.7 \\
\hline Miradapt & MIR & Chemical & Barium glass + Silica & 80.9 \\
\hline Occlusin & OCL & Light & Barium glass + Silica & 85.2 \\
\hline$P-30$ & P 30 & Light & Zinc glass & 85.6 \\
\hline
\end{tabular}

本実験に使用した材料とその略記号を Table 1 に示 す。市販のE歯部用コンポジットレジン 9 種と前歯部用 コンポジットレジン 1 種を実験に供した。P 30 と OCL だけが光重合型レジンで, その他は化学重合型レジンで ある。硬さの実験に先立ち, 各コンポジットレジンの フィラー含有量 (重量\%) を算出した。化学重合型レジ ンの場合は，ユニバーサルペーストとキャタリストペー ストの重量比を $1 / 1$ とし練和重合させたものを, 光重 合型レジンの場合は, 光照射器 (DEMETRON 社製, OPTILUX）により重合硬化させたものを用いた。各々 の硬化物を $800^{\circ} \mathrm{C}$ 電気炉中で加熱してマトリックスを焼 却した。焼却後に残ったフィラーの重量含有率を求め, フィラーの種類とともに Table 1 に付記した。

\section{実験方法}

硬さ試験に用いた試験片は次の方法に従って作製し た。化学重合型レジンはユニバーサルペーストとキャタ リストペーストの重量比を $1 / 1$ とし，30 秒練和した 後シリンジを用いて直径 $5 \mathrm{~mm}$, 高さ $5 \mathrm{~mm}$ のテフロン モールド中に注入した。上下をスライドガラスで圧接し て重合硬化させた。光重合型レジンでは同じモールドを ガラス練板上に置き, $2.5 \mathrm{~mm}$ ずっ 2 回に分けて塡塞 し, 光照射器 (DEMETRON 社製, OPTILUX) を用 いて各填塞毎に 60 秒間光照射した。硬化後のレジンを $37^{\circ} \mathrm{C}$ 恒温恒湿器（TABAI 社製, LHL- 110) に保管し た。1 時間後，エメリー・ペーパーを $\# 240 ， 400 ， 600$ の順に用いて, 試験片の両面の表層を除去した後, 研磨 用アルミナNo.2000でバフ研磨を行った。この研磨操 作により両側の表面をそれぞれ $0.7 \mathrm{~mm}$ 削除し, 両面が
平行になるようにして実験に供した。

硬さの測定は微小硬度計（島津社製，M 型）を用い て負荷荷重 $50 \mathrm{~g}$, 負荷時間 10 秒の条件で試験片表面の ヌープ硬さを求めた。測定は 7 回行い, 最大値と最小値 を除いた $5 つ の$ 値の平均值を硬さとした。

温度変化の実験には各試験片を $37^{\circ} \mathrm{C}$ 空気中ならびに 水中に 10 日間保存したのち, 硬さ試験の直前に温度の みを $25,37,50,60,70^{\circ} \mathrm{C}$ 上変化させ, 各温度に 5 分 間静置後それぞれの硬さを求めた。

またエタノールおよび有機酸の影響をみるため, 空気 中保存後の試験片を $37^{\circ} \mathrm{C}$ のエタノールならびに 3 種の 酸（酢酸, プロピオン酸, 乳酸)に 24 時間浸漬し ${ }^{3)}$, そ れらの硬さの測定む行った。なお空気中に保存したもの をコントロールとした。

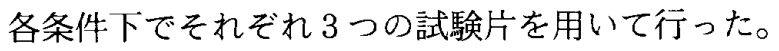

\section{結果}

温度变化による硬さの影響を Fig. 1 に示す。各材料 とも保存条件にかかわらず，温度の上昇につれて硬さの 減少が認められた。しかし $25^{\circ} \mathrm{C}$ と $37^{\circ} \mathrm{C}$ ならびに $60^{\circ} \mathrm{C}$ と $70^{\circ} \mathrm{C}$ との間においては大きな差は認められなかった。 水中保存後, $25^{\circ} \mathrm{C}$ での硬さを研磨直後に比べると, CLP $(\mathrm{P}<0.05), \mathrm{CLF}, \mathrm{PAL}, \mathrm{MAP}, \mathrm{P} 30(\mathrm{P}<0.01)$ が小さくなった。空気中保存のものは, MIR を除いて 変化が見られなかった。また, 空気中保存の P 30 を除 いて他の材料はすべて温度と硬さ之の間に負の相関が認 められた。各材料とも水中での硬さは空気中のものより 小さかった $(\mathrm{P}<0.01)$ 。

また温度の上昇によって結晶フィラーを含むレジン 

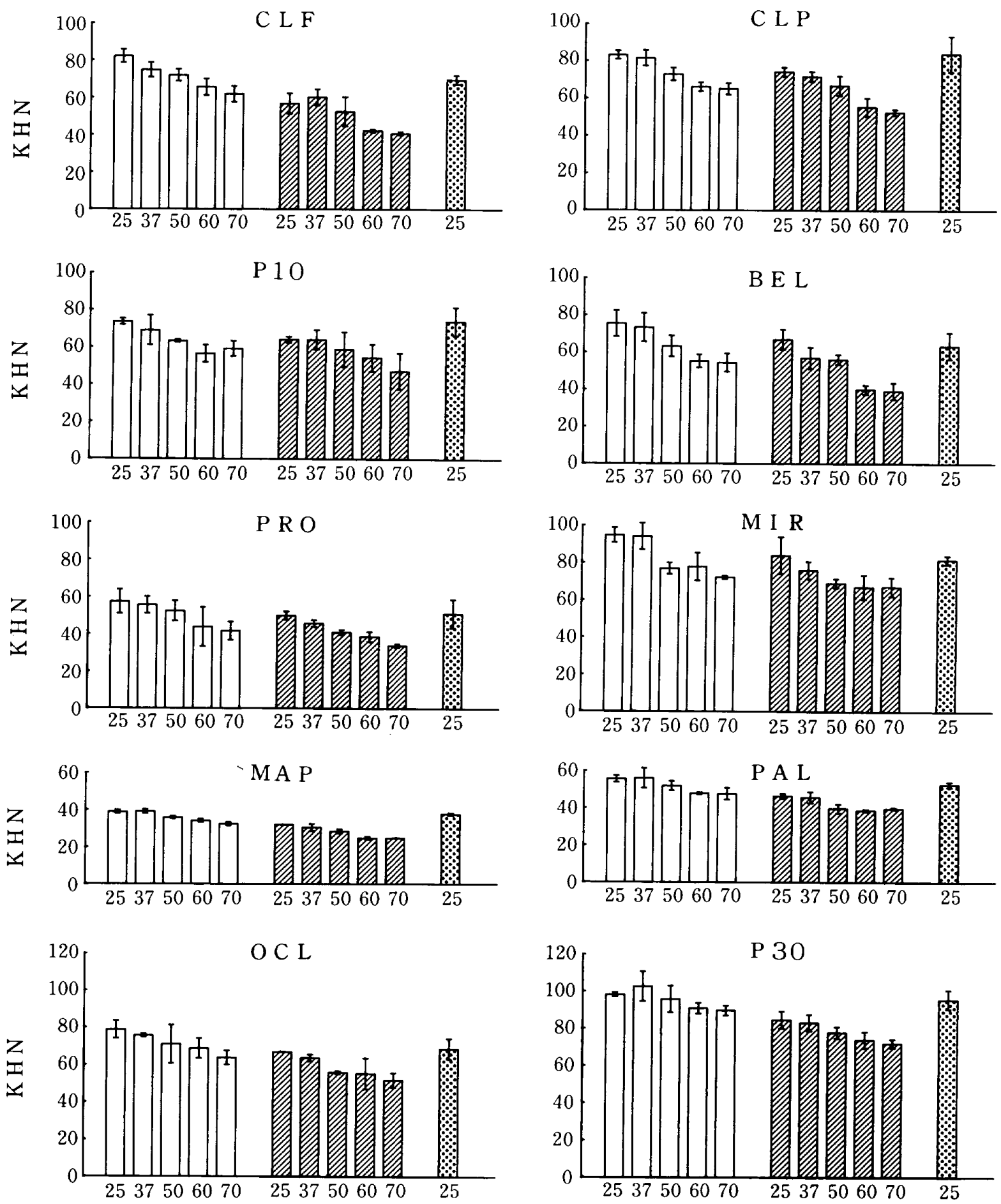

Temperature $\left({ }^{\circ} \mathrm{C}\right)$

Temperature $\left({ }^{\circ} \mathrm{C}\right)$

Fig. 1 Knoop hardness numbers of composite resins stored at various temperatures.
$\square$ stored in air
$\bigotimes$ stored in water
:-9 immediately after polishing 

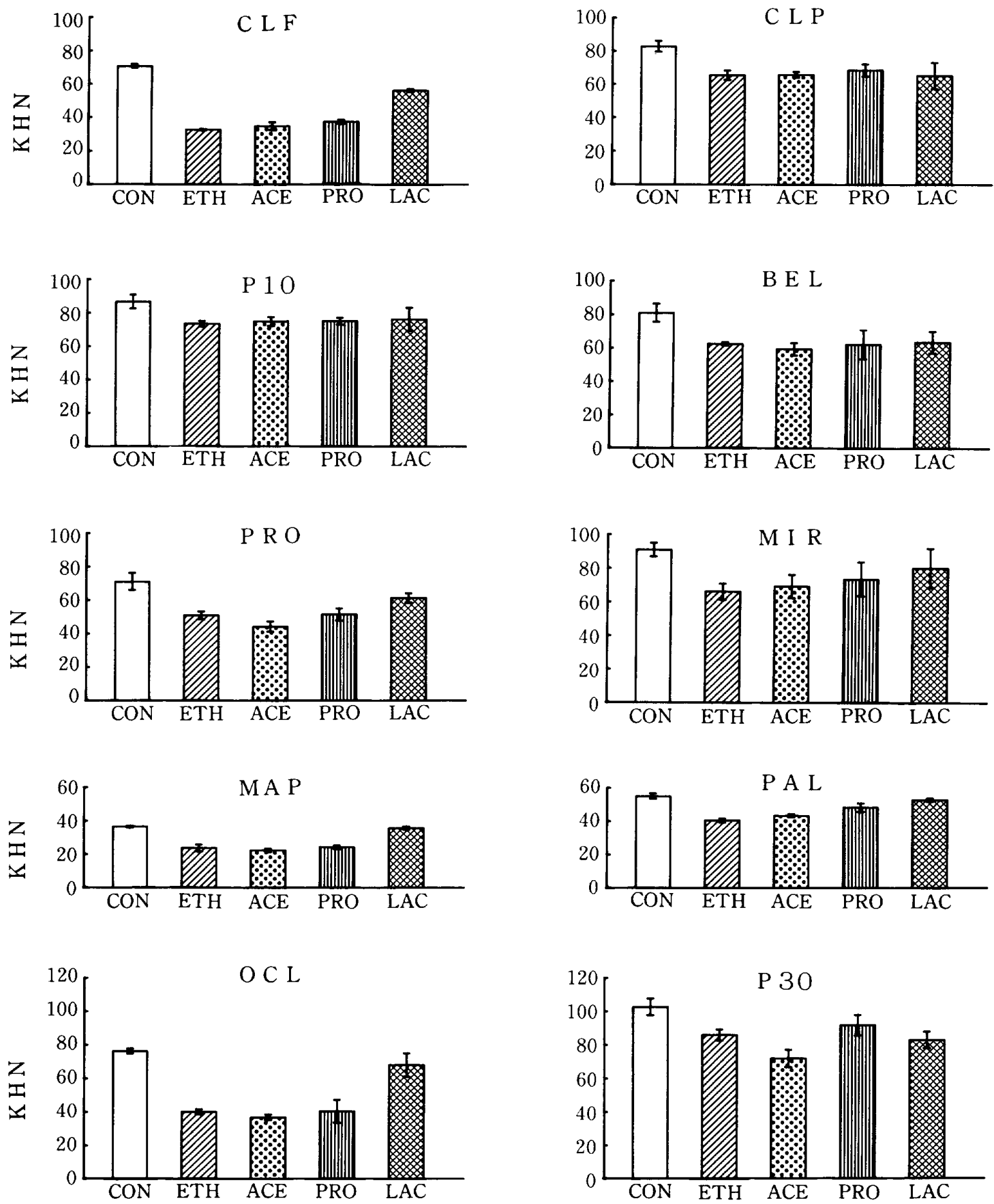

Fig. 2 Knoop hardness numbers of composite resins stored in ethanol and organic acids.

$\square$ control

$Q 7$ stored in ethanol

::- stored in acetic acid

IIII stored in propionic acid

stored in lactic acid 
(CLF, CLP, P 10, BEL) の硬さの減少が大きくな る傾向にあり, フィラー量による影響は認められなかっ た。

エタノールおよび有機酸に浸漬した場合の硬さの変化 を Fig. 2 に示す。各材料ともエ夕ノールおよび有機酸 に浸漬した後の硬さはコントロールの場合より小さかっ た。浸漬後の硬さをみると，エタノールと酢酸による硬 さの減少が最す著しく，次はプロピオン酸であったが， 乳酸による影響は他の 3 種（プロピオン酸, 酢酸, エ夕 ノール）と比べて少ない傾向にあり，乳酸に浸漬した MAP, PAL, MIR とOCL の硬さはコントロールと比 較して有意差は認められなかった。

\section{考察}

且歯部用コンポジットレジンは物性の改良によって臨 床で使用される頻度が多くなってきた。しかし曰歯部用 コンポジットレジンは口腔内においては咀嚼による外力 を受けるばかりでなく，摄取した飲食物からの温度変化 を受けたり，プラークや飲食物などに起因する有機酸や エ夕ノールと接触する機会も多く，これらによるレジン の劣化は無視できない。そこで今回はコンポジットレジ ンに与える温度変化やエタノールおよび有機酸による影 響を表面硬さの変化をむとに検討した。

各コンポジットレジンとも温度の上昇により表面硬さ が小さくなる傾向か認められた。コンポジットレジンの マトリックスは温度によってかなり軟化するため ${ }^{52}$ ，こ の変化によってコンポジットレジンの表面硬さが小さく なったものと考えられる。また硬さの減少量はフィラー 量との相関はなく，硬い結晶フィラーを含むレジンがよ り軟らかい非結晶フィラーを含むむのより大きい（P< 0.01）ことから，フィラーとマトリックスの硬さの差が 大きいもの程温度の影響を受けやすいものと考えられ る。臨床においては, レジンの摩耗は含有するフィラー の量よりもその硬さの影響を受け易く，硬い結晶フィ ラーを含むレジンの方が摩耗量む大きいとの報告(10-12)が あり，これは今回の実験結果から温度变化による影響が 原因の一つであることが予想できる。

本実験に用いたエタノールおよび有機酸（酢酸，プロ ピオン酸と乳酸）は日常の飲料やプラーク中に存在して いるものである ${ }^{1,2)}$ 。Asmussen (1984 年) $)^{3)}$ や Wu $(1982 \text { 年 })^{8)}$ らはエタノールおよび有機酸がコンポジッ トレジン中の Bis-GMA 系のポリマーを軟化すると報告 している。今回の結果も乳酸を除いて他の 2 種類の有機 酸掞よびェタノールが各コンポジットレジンの表面硬さ
を著しく減少させたことから，Asmussen やWu らの 研究結果と一致している。この理由としてェタノール, 酢酸およびプロピオン酸はコンポジットレジンのマト リックスを軟化する作用，すなわち溶解性パラメーター が大きいためであろうと考えられる。また有機酸の中で は乳酸の分子量が最む大きく、コンポジットレジンに対 する如やレジンの表層内への浸透能は他の酸と比べて 小さいため，表面硬さの減少の幅が少なかったもの上思 われる。

コンポジットレジンの表面は温度変化や種々の有機酸 あるいはェタノールなよ゙の影響を受け，軟化することが 明らかとなった。レジンの軟化は耐摩耗性の低下を起こ し，その結果レジンの寿命を短くすることになる。今回 の結果から，口腔内での環境変化に影響されないべース レジンの開発や添加するフィラーの種類，量，大きさな どを検討する必要のあることが示唆された。

\section{結 論}

コンポジットレジンが温度変化 $\left(25 \sim 70^{\circ} \mathrm{C}\right)$ ならび にエタノールおよび 3 種類の有機酸（酰酸，プロピオン 酸と乳酸）からうける影響を表面硬さで検討した。

各レジンと屯保存条件にかかわりなく，温度の上昇に つれて硬さが減少した。硬さの減少量は硬い結晶フィ ラーを含有するレジンの方がより軟らかいフィラーを含 有するものより大きかった。

エタノールおよび有機酸に浸漬したレジンの硬さはコ ントロールの值より小さく, プロピオン酸, 酢酸, エ夕 ノールの順に小さくなった。乳酸に浸漬したものの硬さ の変化はほとんよ゙認められなかった。

\section{引用文献}

1) Geddes, D. A. M. : The production of L $(+)$ and D (-) lactic acid and volatile acids by human dental plaque and the effect of plaque buffering and acidic strength on pH. Archs Oral Biol. 17 : $537-545,1972$.

2) Geddes, D. A. M. : Acids produced by human dental plaque metabolism in situ. Caries Res. 9 : $98-109,1975$.

3 ) Asmussen, E. : Softening of BISGMA-based polymers by ethanol and by organic acids of plaque. Scand. J. Dent. Res. $92: 257-261,1984$.

4) Kao, E. C. : Influence of food-simulating solvents on resin composites and glass-ionomer restorative cement. Dent. Mater. 5 : $201-208,1989$.

5 ) Greener, E. H., Greener C. S. and Moser, J. B. : The 
hardness of composites as a function of temperature. J. Oral Rehabil. 11:335-340, 1984.

6) Draughn, R. A. : Effect of temperature on mechanical properties of composite dental restorative materials. J. Biomed. Mater. Res. 15:489-495, 1981.

7 ) 的野良次, 松崎義美, 穂坂正浩, 木下亮子：修復材料の 圧縮強さにおよぼす温度の影響. 日歯保誌 $20 ： 110$ $115,1977$.

8) Wu, W. and Mckinney, J. E. : Influence of chemicals on wear of dental composites. J. Dent. Res. $61: 1180-1183,1982$.

9 ) Roulet, J. F. and Walti, C. : Influence of oral fluid on composite resin and glass-ionomer cement. J.
Prosthet. Dent. 52: $182-189,1984$.

10) Mitchem, J. C. and Gronas, D. G. : In vivo evaluation of the wear of restorative resin. J. Am. Dent. Assoc. $104: 333-335,1982$.

11) Heymann, H. O., Wilder, A. D., May, K. N. and Leinfelder, K. F. : Two-year clinical study of composite resins in posterior teeth. Dent. Mater. $2: 37$ $-41,1986$.

12) Christensen, R., Christensen, G. and Bangerter, V. : 3-Year in-vivo comparison of 7 posterior resins with silver amalgam. J. Dent. Res. 66:211, 1987. 